\title{
Community Practice
}

National Cancer Institute

\section{Source}

National Cancer Institute. Community Practice. NCI Thesaurus. Code C15937.

Healthcare services rendered within a given population or segment of a society. 